\title{
2.2
}

\section{Appropriate Policy Tools to Manage Capital Flow Externalities}

\author{
Refet S. Gürkaynak
}

\begin{abstract}
Central banks are at the forefront of cyclical policymaking. They therefore become natural candidates to take over all cyclical policy objectives. This is often the case in policies for controlling capital inflows. Giving the duty of controlling capital flows to central banks, explicitly or implicitly, without giving them the appropriate policy tools, leads to inefficient outcomes. It is clear that when a central bank has to use its interest rate tool to satisfy multiple objectives, it will have to make sacrifices. More subtly, but perhaps more importantly, when central banks incur the cost of capital inflows, mostly in terms of taking the public blame, other policymakers often engage in policies that have the side effect of increasing these flows. It then becomes doubly important to give the capital flow management mandate to the policymaker who fosters the inflows, so their possible negative effects will be internalized.
\end{abstract}

Keywords: monetary policy; optimal policy mix; policymaker incentives

Stiglitz, Joseph E. and Refet S. Gürkaynak (eds). Taming Capital Flows: Capital Account Management in an Era of Globalization. Basingstoke: Palgrave Macmillan, 2015. DOI: $10.1057 / 9781137427687.0010$. 


\section{Introduction}

Capital flows continue to be an important topic of policy discussion and academic research. A large part of the policy discussion and most of the recent academic research is about the monetary policy response to capital flows. I will argue that this poses an ill-formed question that effectively implies a particular answer and that asking the question in a monetary policy-centric way most likely leads to suboptimal policy advice.

A precursor question to appropriate policies for controlling capital flows is why capital flows need to be controlled. The literature offers several answers to this question, including the pain associated with sudden stops, boom-bust episodes associated with capital flows, noninternalized systemic currency risk created by borrowing in foreign currencies, and currency appreciations being followed by devaluations rather than depreciations. In this essay, I will remain agnostic about why capital flows need to be controlled or regulated, and assume that capital inflows that are too high by some metric are detrimental to social welfare. My concern is about the domestic policy game played by various policymaking bodies, each of which may have several policy objectives, loss functions, and relevance to capital flows, both in causing and regulating them.

It is easiest to think of a policy environment that is populated by a fiscal and monetary policymaker, although adding a separate bank regulator or other economic policymakers would not change the substance of the argument. There is little literature on monetary and fiscal policy coordination, but monetary policy questions dominate the optimal policy literature. Hence, the question of how best to regulate capital flows gets turned into how best to use monetary policy to regulate capital flows. The additional constraint imposed within the second question, that policy is to be carried out by the monetary policymaker, under most circumstances already answers the question and leads to a policy mix that is inferior to the one that would be realized had the first question been answered.

As I will argue below, without building a formal model, to the extent that monetary policy has any impact on currency flows, which it surely does, optimal monetary policy will include a response to currency flows, if currency flows are in the social welfare function. In fact, this is true for about anything in the social welfare function: monetary policy 
affects output and inflation, and there is very little in a country that is not affected by these two; hence, anything that enters the social welfare function will turn out to elicit a monetary policy response, at least by changing the weights of the monetary policy response to output and inflation. Thus, monetary policy is affected by and responds to a plethora of concerns, over and above targeting inflation, which is the only viable long-run objective for monetary policy.

My argument is that the standard line of reasoning is fundamentally flawed. If the policy focus is limited to a single policy instrument, optimally that instrument will be set to satisfy all arguments of the social welfare function that it can affect and will respond to each, depending mostly on their weights in the social welfare function. This does not mean that that policy instrument should be used to address all of those concerns to some extent; it only means that if that is the only policy tool available, it will have to be used to address all welfare relevant variables.

If there are multiple policy instruments, each of these may be optimally utilized to address some of the variables that enter the social welfare function. In that case, it may not be optimal for monetary policy to respond to capital flows significantly, if at all. Capital flows may be better dealt with by bank regulation or fiscal policy - taxes on capital inflows. But this is not the only reason why the burden of all policy relevant issues should not be on the central bank.

Other than the fact that monetary policy may not be particularly effective in dealing with many kinds of economic issues, having the central bank responsible for dealing with everything creates two other problems. First of all, by pursuing multiple goals, the central bank has to sacrifice its primary goal of inflation stabilization. This is a large cost. More subtly, but as importantly, if it is the duty of the central bank to control capital flows (or meet other objectives), and the cost of not being able to do so, in terms of shame, criticism, or reappointment, is borne by the central bank, then other policymakers will have incentive to engage in behavior that disregards the consequences of their policies on capital flows. In particular, a fiscal policymaker who prefers more growth to less may engage in expansionary policies that, as a byproduct, increase capital inflows, and not care about these because dealing with capital flows is in the central bank's objective. This would lead to a suboptimally high increase in demand by the fiscal authority, which makes the job of the central bank even harder.

In the rest of this essay, I expand this argument. 


\section{The policy game and competing objectives}

An extremely important paper by Leeper (1991) focuses on the interaction between monetary and fiscal policymakers. Leeper makes the observation that fiscal and monetary policymakers have different objectives. The monetary policymaker wants to control inflation, and hence limit monetizing the government debt, whereas the fiscal policymaker prefers to spend but not tax. These two are bound together by the government budget constraint, which has to hold over time. That is, in present value terms, spending either has to be funded by taxes or by monetary expansion.

If both policymakers insist on maximizing their objectives without regard for the behavior of the other, the budget constraint is violated, as spending will neither be funded by taxes nor by seigniorage. This, then, cannot be an equilibrium. If neither tries to maximize their objectives (follow activist policies) then the price level will be indeterminate, which again is not an equilibrium. ${ }^{1}$

This leaves two equilibria: one where monetary policy is dominant and fiscal policy takes monetary policy as given; another where fiscal policy is dominant and monetary policy works to satisfy the government budget constraint. Clearly, in the first case, inflation is low, and the fiscal policy is bounded by tax revenues, whereas in the second case, monetary policy has to create seigniorage revenue to fund the fiscal policy, which it takes as given.

One could imagine extending this framework in many dimensions, including a policy game between the central bank and the bank regulator. Here, I would like to apply this line of thought to capital flows. In particular, I would like to think of an open economy framework where there are fiscal and monetary policymakers as well as a bank regulator. It would suffice to consider the fiscal and monetary policymakers but adding the bank regulator as a separate entity helps make a fuller case.

I think of a central bank that prefers to control inflation, a bank regulator who is not troubled by foreign borrowing or credit expansion of banks, and a fiscal policymaker who prefers expansionary policies. I will abstract from the government solvency concern by assuming that the fiscal policymaker does not run intertemporally unsustainable policies but prefers to choose the most expansionary policies among the admissible (in satisfying the government budget constraint sense) in the absence of other concerns. 
Standard open economy models tell us that capital inflows are stoked by fiscal expansion, due to both the borrowing requirement of the government and the higher activity and interest rates that entice foreign investors. Thus, high capital inflows are a byproduct of expansionary fiscal policy.

Before thinking about the consequences of the policy game this setting implies, a detour into optimal policy discussions is in order.

\section{Optimal policy considerations}

The modern literature on optimal monetary policy begins with the influential work of Rotemberg and Woodford (1997). They were the first to show that one can analyze optimal policy in a general equilibrium framework without assuming an ad hoc loss function for the policymaker but rather by using the utility function of the representative agent as the welfare metric. Doing this is technically demanding and requires a second order approximation to the utility function.

This method is now standard in the literature and has been used to show that monetary policy in the standard models maximizes welfare by putting a high weight on inflation stabilization. The subsequent research used this methodology to study optimal monetary policy in a variety of settings. In some cases, the question was whether and to what extent to respond to exchange rates, in some others, the optimal monetary policy reaction to credit growth, and so forth.

In these studies, to the extent that a model variable affects utility over and above its impact on inflation and output, optimal monetary policy always responds to this variable. Otherwise, the additional variables change the reaction to inflation and output, rather than affecting optimal policy directly. But in either case, it is optimal for monetary policy to change when these variables change.

At this point, it is worth asking why the question is phrased as an optimal monetary policy question rather than an optimal policy question. The answer is not obvious. Cyclical economics research, until the crisis, has focused on monetary policy because this is the standard cyclical stabilization tool. Rotemberg and Woodford asked their question as an optimal monetary policy question and defined the literature in this way. It is likely that this is research "habit."

Political economy also clearly plays a role. Difficulties in political decision-making in many countries force independent central banks to 
take on additional roles and to think about how best to fulfill these new mandates. A detailed discussion of the political economy aspect - of why central banks are becoming ever more central to all kinds of policymaking - is beyond the scope of this paper, but I will argue that the outcome of this has not been welfare-maximizing for the public.

Thus far, we have briefly covered both components of the central argument of this essay: when there are multiple policymaking bodies, economic policy also involves a game between these decision-makers with important welfare consequences, and when we phrase optimal policy questions as optimal monetary policy questions, it turns out that optimal monetary policy responds to everything that affects households' welfare.

It is possible to put these two ideas together in the context of optimal policies to manage capital flows.

\section{Optimal policies to manage capital flows}

The optimal policy to manage capital flows is almost always thought of as a monetary policy application. In practice, the more successful capital inflow deterrents have been non-monetary policy, in particular non-interest rate policies. The South Korean experiment is a good example of using non-monetary policy tools to stem capital inflows (Shin, 201x). The academic literature, however, focuses on monetary policy, and in many emerging economies (and certainly in Turkey), politicians are happy to give the responsibility of dealing with capital flows to the central bank, without regard to whether the central bank has the right tools for the duty. Very often, dealing with capital flows requires lowering interest rates to discourage large inflows, but low interest rates are also expansionary for the domestic economy and may not be the right policy choice, say, for an inflation-targeting central bank.

The fact that giving multiple objectives to a policymaker with a single policy tool will lead to a trade-off between various objectives is clear. I will dwell on this point briefly and then turn to the subtler but equally important issue of distorting incentives for other policymakers by making the central bank suffer for the increased capital inflows, which are often driven by other policies in the country.

Basic control theory tells us that one control variable cannot exactly satisfy two objectives, unless those objectives happen to overlap. For 
example, in the simplest Dynamic New Keynesian models, closing the output gap and achieving price stability turn out to be the same objective (the divine coincidence), and therefore optimal monetary policy produces both zero inflation and output at its potential level. This, however, only happens in the simplest of models. The normal outcome involves a trade-off between competing objectives.

Monetary policy - the setting of short-term interest rates - does have an effect on capital flows. That effect, however, works in two different, offsetting ways. Lower interest rates discourage capital flows, as returns to portfolio investment are reduced. On the other hand, lower interest rates induce higher demand and higher output, creating a cyclical upswing and encouraging foreign capital flows. Further, if lower shortterm interest rates are seen as too expansionary, inflation expectations and inflation risk pricing may go up sufficiently to make long-term interest rates go up, which may again encourage capital inflows.

Assuming that the net effect of lower interest rates on capital inflows is negative and non-negligible, as is often assumed in policy debates, monetary policy may be used to control inflows. Then the problem will be to use interest rates to simultaneously bring inflation to target (assuming that is the main monetary policy goal) and to stem capital inflows. In good times, capital will be flowing in, demand will be high, and there will be inflationary pressures. Lowering the policy rate will deter capital inflows but will also further stimulate demand and increase inflation, rather than controlling it. One the other hand, increasing the policy rate will lower demand and inflation but will also encourage higher capital inflows.

Such trade-offs are standard in economics, and the optimal control solution provides an interior solution, giving some weight to all concerns, depending on how different variables (inflation, output, and capital flows, for example) enter the welfare function, and how the control variable affects these. But to the extent that the control variable has any influence on a variable entering the welfare criterion, the optimal policy response will put at least some weight on it. Hence, optimal policy in this case will sacrifice some inflation - by lowering or not sufficiently increasing the policy rate - to discourage capital inflows. This is the standard channel through which giving an additional duty to the central bank deters it from fulfilling its primary objective of controlling inflation. This is usually why optimal policy (not just optimal monetary policy) entails using a tax - the fiscal tool - to address the capital flow externality, 
leaving monetary policy free to pursue stable prices. It is not surprising that two policy tools - interest rates and a tax - produce a better outcome than interest rates alone. Constraining policy only to interest rates naturally delivers a lower welfare due to the policy trade-off.

There is, however, a second and perhaps more important channel through which additional duties given to central banks are welfare reducing. The usual argument, presented above, treats the behavior of other policymakers, if any, as exogenous to monetary policy. This is often not the case. In particular, behavior of policymakers depends on who takes the blame for bad outcomes. This is where the policy games described above become relevant.

Think of a country with two policymakers: a fiscal authority and a central banker. (The idea extends naturally to more realistic settings where there are separate bank regulators, a ministry of trade, as well as a ministry of finance, etc.) Fiscal expansions lead naturally to higher capital flows both because in many cases governments borrow from abroad directly but also because market interest rates increase due to crowdingout mechanisms, which attract capital inflows. Fiscal expansions fuel demand and also tend to increase inflation.

On the inflation front, the central bank takes the blame because it is the monetary authority's duty to control inflation. Although the fiscal policymaker creates the inflationary impetus, the central bank has to make sure inflation does not increase, which it is able to do with the policy tool available to it. But observe that if the fiscal policymaker internalized the "cost" of higher inflation, there would be less fiscal expansion to begin with. In a situation where an activist central bank is able to undo the inflationary impact of fiscal policy, this does not create a major problem. But when capital flows are also included in the policy considerations, this desirable (in terms of level of GDP, not its composition, which now has higher government spending and lower investment) outcome is no longer attainable.

The issue here is the assumed externality that arises from capital inflows and who bears that cost. It is easy to translate the capital flow externality into a non-pecuniary cost that is borne by a policymaker. In effect, she is criticized for capital flows and suffers a utility cost due to this. This is a reasonable shortcut way of thinking about policy consequences of capital flows. If capital flows only mattered because they affect output and inflation, policy responding to these variables would be sufficient, and there would be no scope for capital flows-specific 
policies. An externality makes capital flows important in its own right and captures the need for policies to cope with capital flows. In a model, a policymaker would act to stem capital flows either because she is trying to maximize welfare, which depends on capital flows, or because she is mandated to do so and not successfully fulfilling the mandate will lead to a utility loss. In this chapter, I think of policymakers as agents with preferences and mandates rather than benevolent welfare maximizers. Hence, the utility cost of capital flows device works nicely. The question is who bears this cost.

This is a key question, as it determines incentives in creating as well as limiting capital flows. This is where the Leeper (1991) framework is helpful in providing a framework to assess the effects of different policymakers bearing the cost of capital flows. One can imagine an equilibrium where the fiscal policymaker bears the cost, as well as one where the monetary policymaker incurs the cost of capital flows.

When the fiscal policymaker bears the cost of capital inflows, she will internalize the capital flow effects of expansionary policies, and hence will stimulate demand less (even if the fiscal policymaker is unable to use the optimal policy tool of imposing a tax on capital flows). The central bank is then free to pursue its inflation-targeting goal, which does not lead to overly expansionary policies and associated capital inflows anyway.

When the monetary policymaker is the one who incurs the cost of capital inflows, as would be the case when controlling capital flows is de facto the central bank's job, fiscal policy will no longer internalize the capital flow costs of expansionary policies, and hence will be too expansionary. In this case, the equilibrium will entail a larger fiscal expansion, more capital inflows, and the central bank that less effectively controls both capital inflows and inflation. Hence, the country will end up having higher capital flows and higher inflation. Notice that this is a different argument from the central bank facing a trade-off between inflation and capital inflow stabilization (that concern is still present); here, the argument is that the size of capital inflows also depends on the behavior of the fiscal policymaker, and that when not given the proper incentive, she will pursue policies leading to increased capital inflows, making the job of the central bank even more difficult.

In the recent past, Turkey experienced a massive increase in government spending, followed by greater demand, and accompanying current account deficits and very large short term capital inflows. Although not 
in its legal mandate, the central bank de facto had the duty of controlling the current account deficit and capital inflows, which, not surprisingly, it was unable to do with its interest rate tool. Although the central bank came up with a variety of creative policies, none of these successfully undid the expansionary effects of fiscal policy and limiting capital inflows (but the capital inflows concern led to lower interest rates and higher inflation). This led the government to criticize the central bank for failing to sufficiently lower interest rates and stem capital inflows. Hence, the government on the one hand implemented the policies that led to the capital inflows, and on the other hand, criticized the central bank for these inflows. Clearly, had the government thought that they would be the ones taking the blame and facing the criticism for the shortterm capital inflows, they would have been more hesitant to engage in the fiscal expansion.

Similar concerns arise for a variety of policy objectives such as bank credit growth, exchange rate appreciation, and so forth. In most cases, there is a natural policymaker who should have the mandate to choose policies, but if such policies are not forthcoming, central banks step in to fill the policy void. But this distorts the incentives of other policymakers. This is most apparent for capital flows in emerging market economies. Thus, it is important for central banks to resist the temptation to be the policymaker of last resort.

\section{Conclusions}

Central banks are at the forefront of cyclical policymaking. They therefore become natural candidates to take over all cyclical policy objectives. This is often the case in policies for controlling capital inflows. Giving the duty of controlling capital flows to central banks, explicitly or implicitly, without giving them the appropriate policy tools, leads to inefficient outcomes. It is clear that when a central bank has to use its interest rate tool to satisfy multiple objectives, it will have to make sacrifices. More subtly, but perhaps more importantly, when central banks incur the cost of capital inflows, mostly in terms of taking the public blame, other policymakers often engage in policies that have the side effect of increasing these flows. It then becomes doubly important to give the capital flow management mandate to the policymaker who fosters the inflows so that their possible negative effects will be internalized. 
The theory of externalities and optimal taxation is very clear in taxing the externality and making the party creating the externality internalize it as optimal policy. This advice is often ignored when dealing with macroeconomics, but it is no less valid here. If capital flows are deemed hazardous at large quantities, they should be taxed. Central banks cannot impose taxes, and thus they have to resort to second-best policies that detract from their primary duties as well. Further, capital flows are often caused by expansionary policies in the recipient county, and fiscal authorities undertake such policies. In this case, giving the capital flow management duty to fiscal authorities would make them internalize the negative side effects and lead to more restrained capital flows to begin with. Hence, it is very rarely the best allocation of duties when central banks shoulder capital flow management mandates.

\section{Note}

1 This is a subtler argument that relies on the technical fact that expectations of inflation and the price level will be determinate either if the central bank reacts strongly to inflation, hence high inflation expectations cannot be rational, or if fiscal policy is lax enough that debt will have to be monetized, hence low inflation expectations cannot be rational. If neither condition holds inflation expectations and the price level will be indeterminate in models with rational agents.

\section{References}

Leeper, E. (1991) “Equilibria Under 'Active' and 'Passive' Monetary and Fiscal Policies," Journal of Monetary Economics 27(1): 129-147.

Rotemberg, J. and M. Woodford (1997) "An Optimization-Based Econometric Framework for the Evaluation of Monetary Policy," NBER Macroeconomics Annual 12: 297-361. 